\title{
DEVELOPMENT OF A GEOPLAYLEARNING MECHANICS AND MOdALITY PRINCIPLE AS A PRESENTATION STRATEGY
}

\author{
Khairuddin Nisa ${ }^{1}$, Che Zalina Zulkifli², and Nor Azah Abdul Aziz ${ }^{3}$ \\ ${ }^{1}$ Excellent Teacher Council Hilir Perak and Bagan Datuk District, Teluk Intan, Perak, \\ Malaysia \\ ${ }^{2}$ Computing Department, Faculty of Art, Computing and Creative Industry, Sultan Idris \\ Education University, Tanjong Malim, Malaysia \\ ${ }^{3}$ Creative Department, Faculty of Art, Computing and Creative Industry, Sultan Idris \\ Education University, Tanjong Malim, Malaysia
}

\begin{abstract}
The main focus of the study is to develop a game-based learning (GBL) Geoplay that can help students to learn according to their cognitive levels. However, there are studies which have shown no consistent evidence GBL can improve cognitive skills.To overcome this problem, GBLGeoplay must be developed needs with a specific cognitive objective, have a mechanics which is based on the real-life scenario and use modality principle as a presentation strategy.Two types of Geoplay have been developed which have similar cognitive objectives and mechanic rules but have different presentation strategy. MANCOVA analysis showed that the groupGeoplay pictures and narration $(P \& N)$ achieved better results in cognitive skills compared to the group Geoplay pictures and on-screen text $(P \& T)$. This study suggests that each GBL development should have specific objectives, real-world mechanics and usevisual with narration as a presentation strategy.
\end{abstract}

\section{KEYWORDS}

Game-Based Learning, Geoplay, Cognitive skills, Mechanics, Modality Principle

\section{Gbladvantange To Cognitive}

The human brain functions by curious and often seeks to ensure its survival. When these two criteria are met, the brain produces neurotransmitters dopamine, a drug which can induce a positive feeling to human beings [1,2]. However, the process of producing neurotransmitters dopamine can only be activated if the person is facing an uncertain outcome. For example, the higher risk, the higher the level of neurotransmitters dopamine produced, thus the level of the positive feeling will also increase [1]. The result of this positive feeling will enable a person to think more flexibly and make better decisions [2]. Based on the articles provided by [1] and [2] we can describe it in Figure 1 below. 


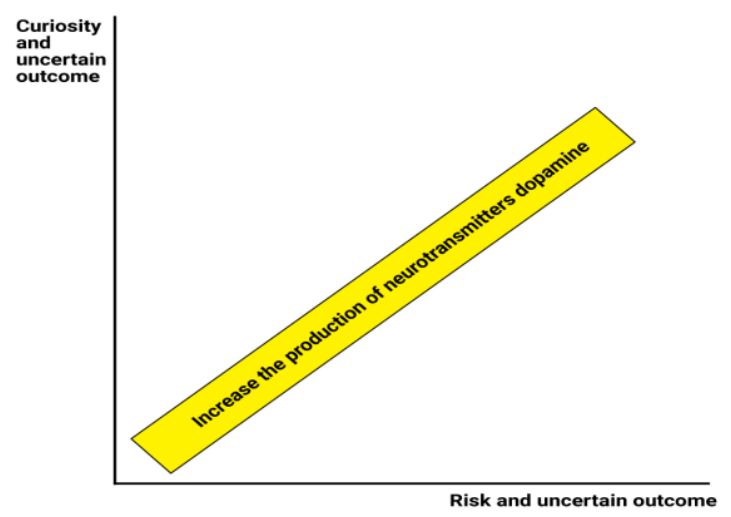

Figure 1.Increase the production of neurotransmitters dopamine

Refer to the Figure 1, it can be assumed that if a human encounter a curiosity in an uncertain outcome and risk in an uncertain condition it can increase the production of neurotransmitters dopamine. If a human can survive in that condition, positive feeling will also increase and enable a person to think more flexible and make better decisions.

The same thing will happen if students use game-based learning (GBL). The human brain will work hard to learn how to survive against toxic mushrooms and fighting a group of giant creature[13]. The point is, the higher the risks encountered in GBL, the higher the positive feeling will be gained. Figure 2 shows how neurotransmitters dopamine can be produced in human brain.

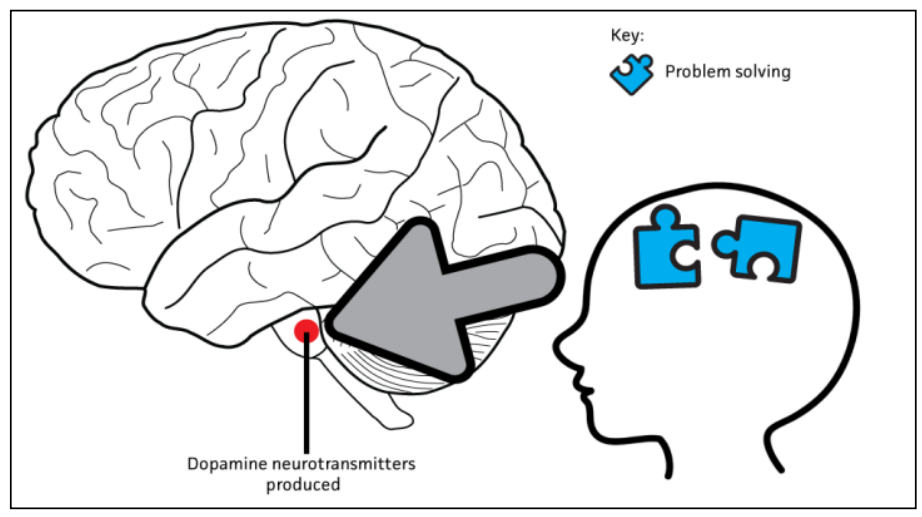

Figure 2.Shows how neurotransmitters dopamine can produce in human brain

Based on Figure 2 above, when a student has curiosity and encounters an uncertain risk while solving the problem in GBL, such as against toxic mushrooms and fighting a group of giant creature, also can increase the production of neurotransmitters dopamine. If the students can solved the problems, the positive feeling will also increase and enable that player or student to think more flexible and make better decisions. There is also a view that GBL neurotransmitters dopamine can produce a positive feeling that allows the player think more innovatively in resolving a problem $[10,15]$. Thus, it is obvious that a GBL development should focus on problems that need to be solved by the players, because when neurotransmitters dopamine produced, it can help to improve students' cognitive skills.

\section{RESEARCH PROBLEM}

Even though GBL can increase the production of neurotransmitters dopamine, a drug which is capable of inducing a positive feeling and enabling the player to think innovatively in solving 
problems, there is not enough evidence that GBL can improve the cognitive skills of the player. For example, researchers have concluded that game-based learning cannot yet revolutionize education $[4,17,20]$. Overall there is not enough evidence to support that using GBL can improve players' cognitive skills[7,20].

There are studies which show that players do not have significant cognitive changes after they played games such as first-person shooter and spatial puzzle. This is because most GBL do not have clear cognitive processes to achieve a learning objective [20]. The second study focuses on GBL known as the e-Bug platform, which has the similar game design objectives for the educational purposes but mechanically different. First GBL e-Bug platform, the player has a mechanic to shoot germs with soap and second e-Bug platform the player has a mechanic of shooting virus with white blood cells. The results show that the first GBL e-Bug platform has achieved a better performance because its mechanics are based on real-world situations where players can logically understand washing with soap can kill germs compared to the situation of killing the virus with white blood cells [7].

Two steps have been taken to resolve this issue. First the GBL developed should have a specific objective of the cognitive skills to be achieved [21]. Second, GBL mechanics should be based on real life scenario [7]. Based on the two suggestions given, the GBL named Geoplay has been developed. Geoplay is designed through a process of gamification that has specific objectives in order to achieve the level of cognitive skills and it has mechanics based on real life scenario [12].

\section{GBL GEOPLAY}

Geoplay is developed for students to learn the topics of wind directions and bearings in Geography skills. This title is chosen to be used in GBL Geoplay because in the Secondary Standard School Curriculum (KSSM) Form 1 Geography, students need to master the level of cognitive thinking skills (TP) such as to remembering, understanding, applying, analysing, evaluating and creating which have been set in the standard performance (SPi) [3].

Furthermore, the topic of wind directions and the bearings are chosen to be used as a Geoplay game after reviewing the both Watters [30] and Trussell [29] that the curriculum of the wind directions and bearings need to be applied in school. However, there is a major constraint in the learning of this topic. It will take half a day for students to master this topic, because the learning activities are done outside the classroom [29,30]. The topic of wind directions and bearings have been suggested as activities in GBL [5]. Through [5] suggestion and using the advantages of GBL which can give students the opportunity to learn through experience $[6,10,11,31]$ has given the idea of developing GBL Geoplay that can be played in the classroom and thus save on learning time because it does not involve management of time and the administration of students outside the classroom

\section{Geoplay Cognitive ObJectives}

Geoplay is developed by focusing on the objective of testing the students' thinking skills based on the Bloom's cognitive taxonomy such as remembering, understanding, applying, analysing, evaluating and creating. Developed GBL should base on Bloom's taxonomy level so that learning objectives are more focused $[10,11,20,27]$. The proposed development of GBL based on Bloom's taxonomy is in alignment with KSSM Form Geography 1 for the topic of wind directions and bearings because students need to master in cognitive thinking skills (TP) of remembering, understanding, applying, analysing, evaluating and creating the SPi. Please refer to Table 1 below. 
The International Journal of Multimedia \& Its Applications (IJMA) Vol.9, No.4/5/6, December 2017

Table 1. Geoplay Objectives Cognitive by Bloom's Taxonomy.

\begin{tabular}{|c|l|l|}
\hline $\begin{array}{c}\text { Bloom's } \\
\text { Taxonomy }\end{array}$ & \multicolumn{1}{|c|}{ Geoplay Activity Suggestions } \\
$\begin{array}{c}\text { TP 1 } \\
\text { Remember }\end{array}$ & $\begin{array}{l}\text { The player needs to determine the } \\
\text { right of wind direction. }\end{array}$ & $\begin{array}{c}\text { Performance Standard (SPi) } \\
\text { KSSM Geography Form 1 } \\
\text { BPK (2015) }\end{array}$ \\
\hline $\begin{array}{c}\text { UP } 2 \\
\text { Understand }\end{array}$ & $\begin{array}{l}\text { Players perform explorations in the } \\
\text { direction of the sun. }\end{array}$ & $\begin{array}{l}\text { Identify the direction by the sun } \\
\text { guide. }\end{array}$ \\
\hline $\begin{array}{c}\text { AP } 3 \\
\text { Apply }\end{array}$ & $\begin{array}{l}\text { The player acts as a warrior who } \\
\text { knows to orient the compass to } \\
\text { determine the direction and identify } \\
\text { the direction by the sun guide to } \\
\text { save the refugees from enemy } \\
\text { attacks. }\end{array}$ & $\begin{array}{l}\text { Oriented the compass to } \\
\text { determine the direction and } \\
\text { identify the direction by the sun } \\
\text { guide. }\end{array}$ \\
\hline $\begin{array}{c}\text { TP } 4 \\
\text { Analyze }\end{array}$ & $\begin{array}{l}\text { A player or a fighter must study the } \\
\text { best possible way of avoiding mines } \\
\text { based on the bearing. }\end{array}$ & $\begin{array}{l}\text { Identify the direction by the sun } \\
\text { guide, orient the compass and } \\
\text { measure the bearing by using a } \\
\text { protractor. }\end{array}$ \\
\hline $\begin{array}{c}\text { TP 5 } \\
\text { Evaluate }\end{array}$ & $\begin{array}{l}\text { The player using maps should decide } \\
\text { the best location based a more } \\
\text { challenging bearing. }\end{array}$ & $\begin{array}{l}\text { Determine the direction and } \\
\text { bearing a location on the map by } \\
\text { using a compass and protractor. }\end{array}$ \\
\hline $\begin{array}{c}\text { TP } 6 \\
\text { Create }\end{array}$ & $\begin{array}{l}\text { Players need to developdefenses to } \\
\text { save refugees by applying the } \\
\text { knowledge of compass reading and } \\
\text { bearing. }\end{array}$ & $\begin{array}{l}\text { Determine the direction and } \\
\text { bearing a location on the ground } \\
\text { by using compass and } \\
\text { protractor. }\end{array}$ \\
\hline
\end{tabular}

Bloom's Taxonomy in KSSM DSKP Form 1 also refers to a level of mastery (TP). For example, TP 1 refers to remember thinking skills, TP 2 is to understand thinking skills, TP 3 is applying thinking skills, TP 4 refers to analysing skills, TP 5 is evaluating thinking skills and TP 6 is creating thinking skills. Examples of Geoplay game based on SPi for TP 6 is that players need to develop defenses to save refugees by reusing the knowledge of compass and bearing. The suggestion activity is different from the prescribed in SPi that students can determine the direction and bearing of a location in the ground by using a compass and protractor. This is because GBL like Geoplay involves the virtual world and for the thinking skills creating proposed in the digital game is to create something based on the initial knowledge gained [10,11]. However, when students have completed the mission in played Geoplay they can be tested based on the reality world.

The theoretical development that will be used to develop Geoplay GBL is cognitive constructivism. The practice of constructivism learning theories in GBL because it's closely related to the development of knowledge structure through experience $[19,23,28]$. The cognitive constructivism practice in Geoplay will occur when students will be tested in stages of cognitive skills to remember, understand, apply, analyze, evaluate and create students through experience during play. 


\section{GeOPlay MeChANiC}

Mechanic is the rules of a game and every rule selected by the player will result in games events $[9,10,26]$. Each GBL design must have a real-world-based mechanic in order to increase the cognitive level of players through a process known as Cognitive Walkthrough for Learning Through Game Mechanics (CWLTGM). The CWLTGM process intends to list every mechanical process to ensure a logical relationship with the real world [7]. Table 2 shows Geoplay mechanics according to CWLTGM.

Table 2. Geoplay mechanics according to CWLTGM.

\begin{tabular}{|c|c|}
\hline $\begin{array}{l}\text { TP } 1 \text { Remember: } \\
\text { Shows the wind } \\
\text { direction. }\end{array}$ & 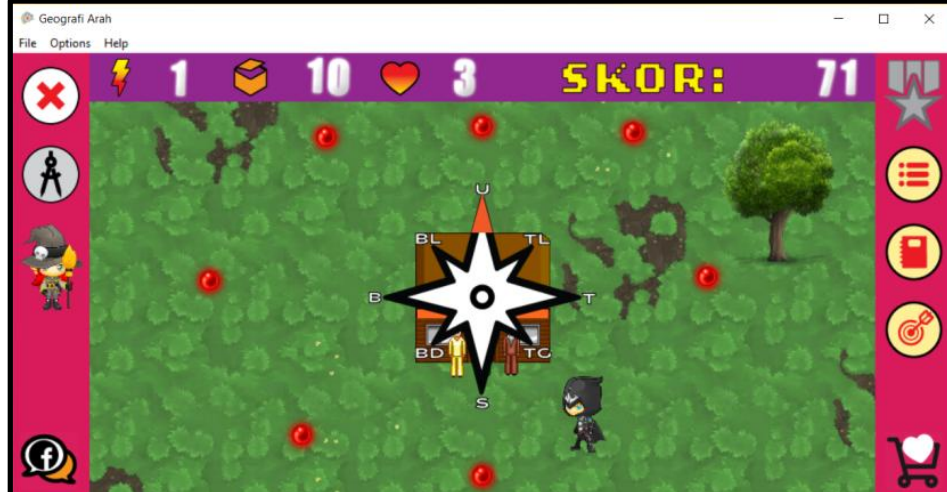 \\
\hline & $\begin{array}{l}\text { Mechanics: The player must pick up the power source in the } \\
\text { right direction. } \\
\text { CWLTGM: Players know in the real world they can move in } \\
\text { the direction they decide. }\end{array}$ \\
\hline $\begin{array}{l}\text { TP 2 } \\
\text { Understand: } \\
\text { Identify the } \\
\text { direction by the } \\
\text { sun guide. }\end{array}$ & $\begin{array}{l}\text { Mechanics: The player must pick up the power source in the } \\
\text { right direction and correctly place the electric suction in the } \\
\text { direction with the sun guide. } \\
\text { CWLTGM: Players know in the real world they can move to } \\
\text { the direction of sunrise and sunset. }\end{array}$ \\
\hline
\end{tabular}




\begin{tabular}{|c|c|}
\hline \multirow[t]{2}{*}{$\begin{array}{l}\text { TP 3 Apply: } \\
\text { Oriented the } \\
\text { compass to } \\
\text { determine the } \\
\text { direction and } \\
\text { identify the } \\
\text { direction by using } \\
\text { the sun as a } \\
\text { guide. }\end{array}$} & 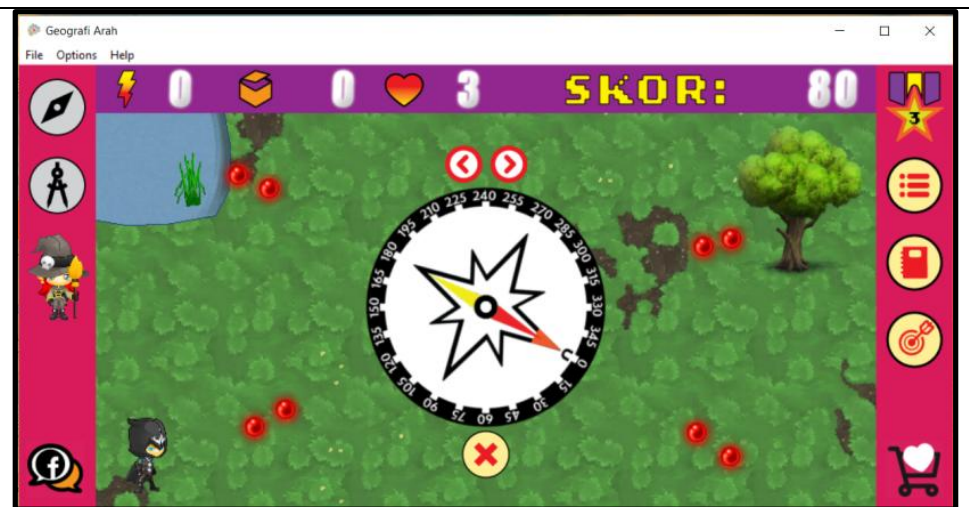 \\
\hline & $\begin{array}{l}\text { Mechanics: Players need to know how to orient the compass } \\
\text { in order to acquire the power source and place the electric } \\
\text { suction in the right direction. } \\
\text { CWLTGM: The player understands the usage compass using } \\
\text { in Geoplay is common with the actual compass in the real } \\
\text { world. }\end{array}$ \\
\hline \multirow[t]{2}{*}{$\begin{array}{l}\text { TP } 4 \text { Analyze: } \\
\text { Determine } \\
\text { directions by } \\
\text { using the sun as a } \\
\text { guide, orient } \\
\text { compass and } \\
\text { measure the } \\
\text { bearing by using } \\
\text { protractor. }\end{array}$} & KR R: \\
\hline & $\begin{array}{l}\text { Mechanics: Players need to know to orient the compass to } \\
\text { take on the power source and place the electric suction in } \\
\text { the right direction. Players also need to know the basics in } \\
\text { using the protractor to obtain a mine detector. } \\
\text { CWLTGM: Players can apply the term as in the classroom. }\end{array}$ \\
\hline \multirow[t]{3}{*}{$\begin{array}{l}\text { TP } 5 \text { Evaluate: } \\
\text { Determine the } \\
\text { direction and } \\
\text { bearing a location } \\
\text { on the map by } \\
\text { using a compass } \\
\text { and protractor. }\end{array}$} & 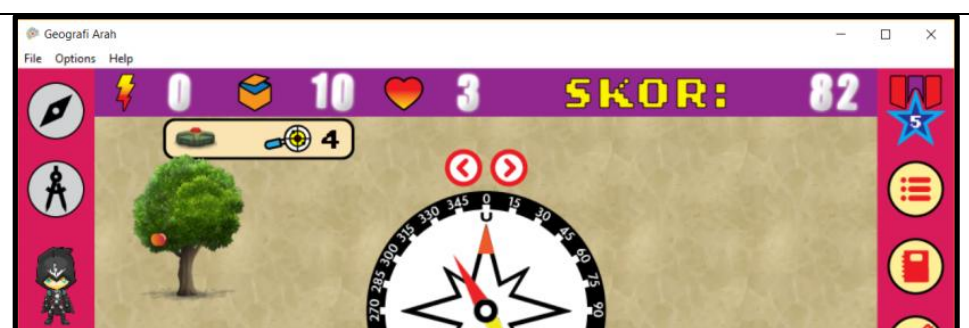 \\
\hline & (A) \\
\hline & $\begin{array}{l}\text { Mechanics: In addition to being able to orient the compass, } \\
\text { players also need to use the protractor based on the map to }\end{array}$ \\
\hline
\end{tabular}


The International Journal of Multimedia \& Its Applications (IJMA) Vol.9, No.4/5/6, December 2017

\begin{tabular}{|c|c|}
\hline & $\begin{array}{l}\text { get a mine detector. } \\
\text { CWLTGM: The player understands in the real world that if } \\
\text { human step on the mines it can cause death. Therefore, } \\
\text { players must know the right direction to be safe. }\end{array}$ \\
\hline $\begin{array}{l}\text { TP } 6 \text { Create: } \\
\text { Determine the } \\
\text { direction and } \\
\text { bearing a location } \\
\text { on the ground by } \\
\text { using compass } \\
\text { and protractor. }\end{array}$ & 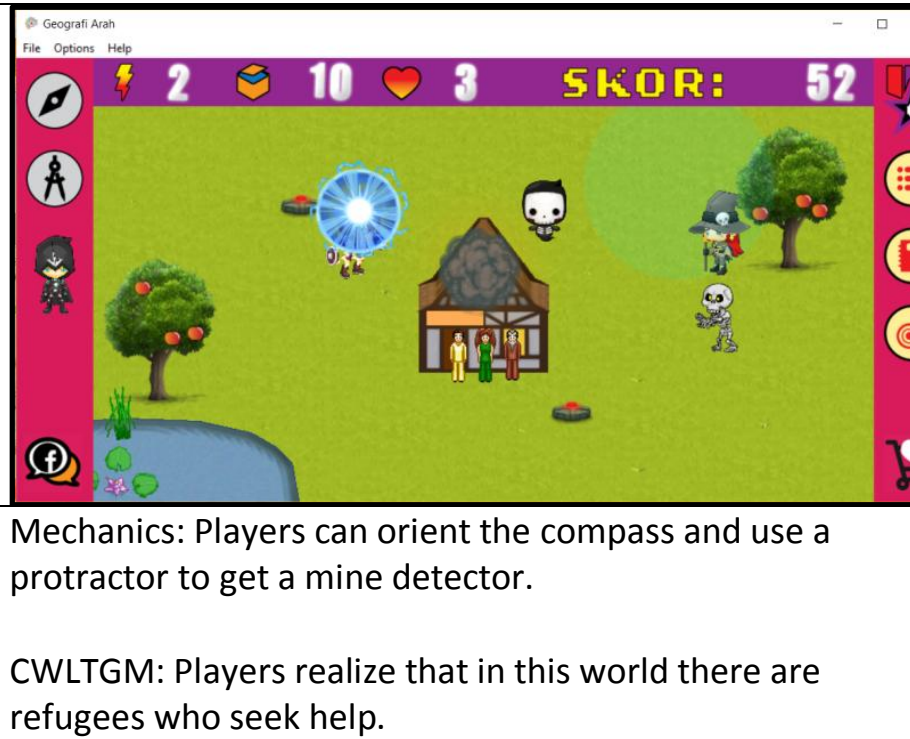 \\
\hline
\end{tabular}

\section{Geoplay Modality Principle}

Modality principle means people learn more deeply from pictures and spoken words than from pictures and printed words[16,20,22,25]. The principle of modality has been chosen for this study because there are students and teachers have a perception that pictures and printed word or text on-screen can increase knowledge[8]. For this research two types of Geoplay have been developed. These games have similar cognitive objectives and mechanic rules but have different presentation strategy,i.e. theGeoplay $\mathrm{P} \& \mathrm{~N}$ have pictures and narration as a presentation strategy, while the Geoplay P\&T have pictures and on-screen text as a presentation strategy. Table 3 shows differences Geoplay presentation strategy.

Table 3. Differences Geoplay Presentation Strategy.

\begin{tabular}{|c|c|}
\hline Geoplay P\&N & Geoplay P\&T \\
\hline$\sum_{n}^{N}$ &  \\
\hline
\end{tabular}






For the Geoplay $\mathrm{P} \& \mathrm{~N}$, a player can view pictureswith narrationwhen exploring objective and tutorial for the topic of wind directions and bearings. Whereas the Geoplay P\&T a player also views the similar pictures and on-screen text that contains the same words as in the narration, but can't hear the narration.Players in Geoplay $\mathrm{P} \& \mathrm{~N}$ can hear objective and tutorial narration repeatedly. They can choose to the next stage after understanding the narration given.Similarly to Geoplay P\&T, players can choose to the next stage after understanding the texts read.

\section{RESEARCH QUESTIONS}

The main purpose of this research is to develop Geoplaywith specific objectives and have realworld mechanics but using different presentation strategy. Further action, GBL Geoplay P\&N and Geoplay P\&T will be played to determine the effect oflower-order thinking skills (LOTS) and higher-order thinkingskills (HOTS) students for the topic of wind directions and bearings. LOTS consist of remembering and understanding, while HOTS consist of applying, analyzing, evaluating and creating[14,24].To perform this study the experimental group will use Geoplay $\mathrm{P} \& \mathrm{~N}$ and the control group will use Geoplay $\mathrm{P} \& \mathrm{~T}$. The following research questions in conducting this Geoplay comparison study.

(1) Are there differences in LOTS achievement between students who have played Geoplay P\&N games and those who played Geoplay P\&T games?

(2) Are there differences in HOTS achievement between students who have played Geoplay $\mathrm{P} \& \mathrm{~N}$ games and those who played Geoplay P\&T games?

\section{MeTHOD}

\subsection{Participants And Design}

This study uses quasi-experimental design and the data analyzed through the quantitative approach. A total of 287 form one students from Hilir Perak and Bagan Datuk districts which involved five urban schools and five rural schools were selected as a sample of the study and divided equally between experimental and control group. Experimental group $(n=143)$ and control group ( $n=144$ ). Multivariate analysis of covariance (MANCOVA)was used to examine the effects of LOTS and HOTS on the experimental and control group. 


\subsection{Experimental Procedure}

Figure 3 shows the procedure followed by the experiment. The 287 students involved have learned the topic of wind directions and bearings with their teacher before. For that reason, students will be divided into experimental group (Geoplay $\mathrm{P} \& \mathrm{~N}$ ) and control group (Geoplay $\mathrm{P} \& \mathrm{~T}$ ) randomly. Before beginning the Geoplay game, each group took a pre-test in 30 minutes. After pre-test, each group will play Geoplay by self-learning in 60 minutes. The experimental group will play Geoplay P\&N and thecontrol group will play Geoplay P\&T separately to avoid discussion and use headphones to avoid noise disturbances while playing and a teacher only acts as a facilitator.

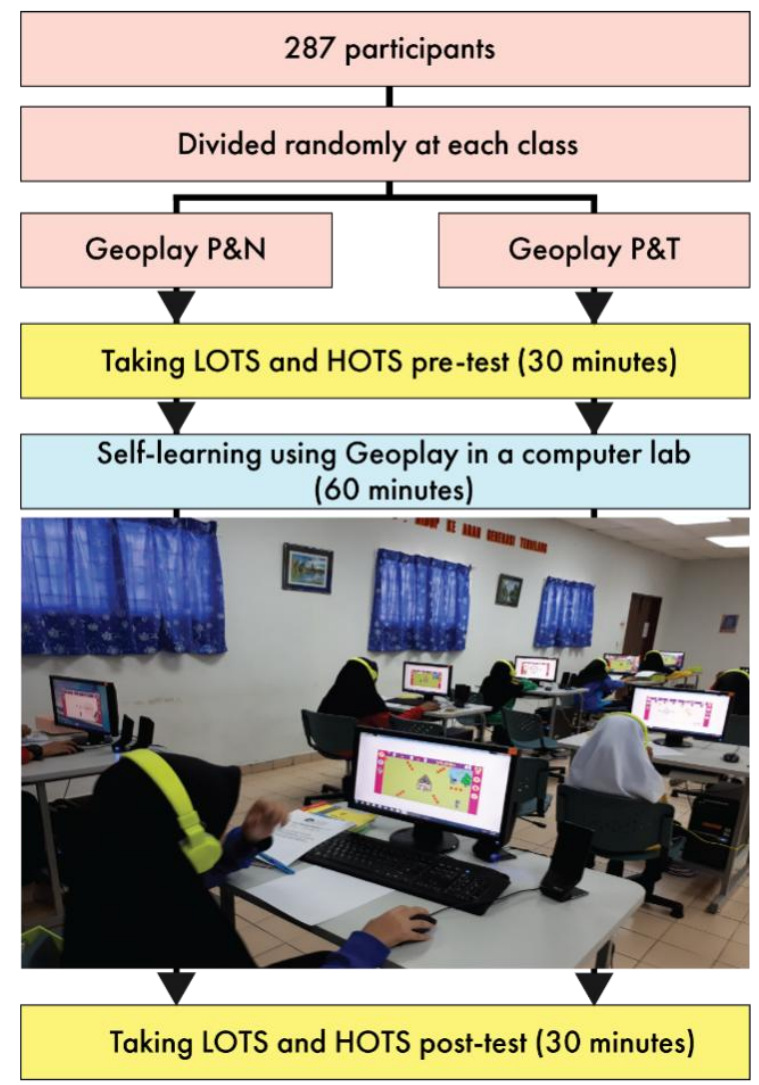

Figure 3.The experimental procedure.

After self-learning using Geoplay $\mathrm{P} \& \mathrm{~N}$ and $\mathrm{P} \& \mathrm{~T}$, each group took post-test in 30 minutes. The Instruments for testing LOTS and HOTS on the topic of wind directions and bearings has gained validity fromGeography Curriculum Development Division and two excellent teachers in Geography. Cronbach's alpha for thisinstrument was 0.85 . This instrument consists 7 items. Item 1 to test cognitive remembering, item 2 to test cognitive understanding, item $3 \mathrm{a}$ and $3 \mathrm{~b}$ to test cognitive applying, item 4 to test cognitive analysing, item 5 to test cognitive evaluating and item 6 to test cognitive creating.Figure 4 showsexample LOTS and HOTS questions. 


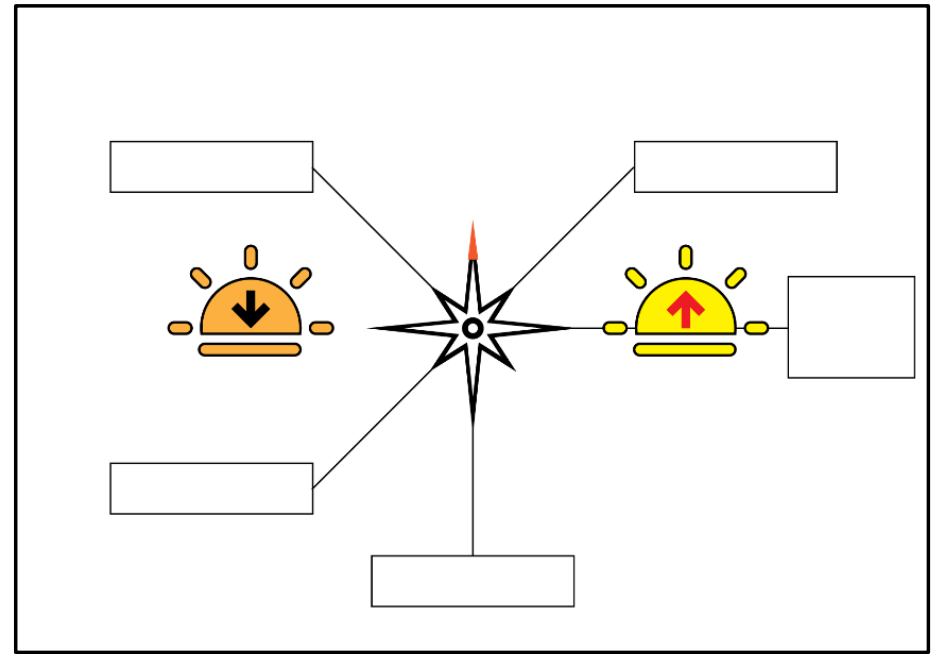

Item 2: LOTS questions.

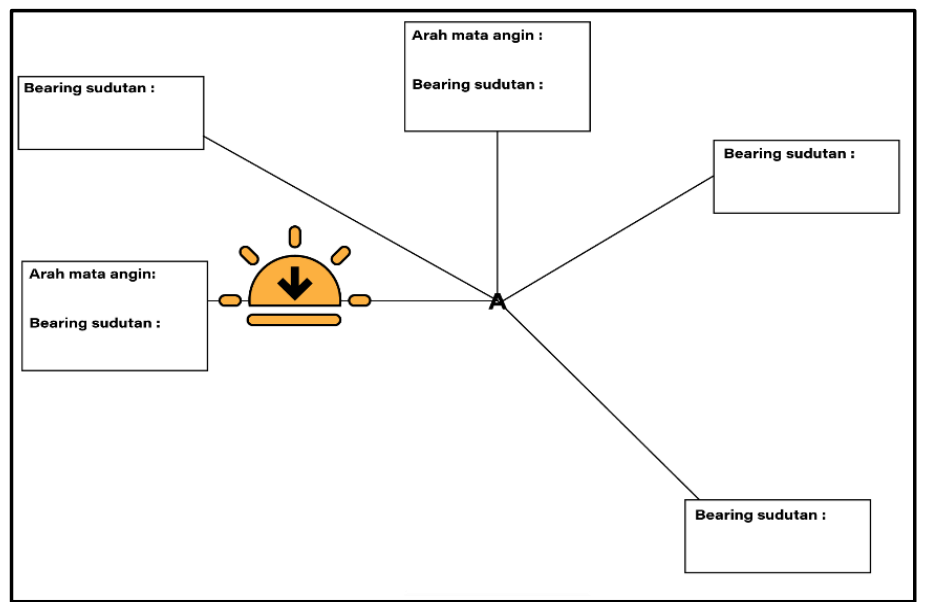

Item 4: HOTS questions based on location in the school.

Figure 4.Example of LOTS and HOTS questions.

Students must understand the direction north, northeast, east, southeast, southwest, west, and northwest by the sun guide to answer item 2.For Item 4 students must determine directions based on location in the school by using the sun as a guide, orient compass and measure the bearing by using a protractor (e.g. $0^{\circ}$ to $360^{\circ}$ ). Score Items 1 and 2 will be combined into LOTS scores. Score item 3a, 3b, 4, 5, and 6 will be combined into HOTS scores.

\section{ReSUlts}

To test the achievement between the post-test result of the two groups, a one-way MANCOVA was performed on the post-test result for LOTS and HOTS. For that test, the pre-test scores provided the covariance, the post-test scores were the dependent variable, and type of game (Geoplay P\&N or Geoplay P\&T) was the fixed factor.

For first research question, a MANCOVA revealed that students in theGeoplay P\&N scored significantly higher on the LOTS post-test than students in the Geoplay P\&T, $F(1,285)=5.57$, $p<.05$.The second research question, also revealed that students in theGeoplay P\&N scored significantly higher on the HOTS post-test than students in the Geoplay P\&T, $F(1,285)=6.65$, $p<.05$. 


\section{Discussions And Conclusions}

The findings show that even Geoplay has specific objectives and have real-world mechanics but have shown the difference in cognitive achievement in LOTS and HOTS because of differences presentation strategy.Figure 5 below can shows, how the cognitive theory of multimedia learning can explain the process of modality principle.



Figure 5: Cognitive theory of multimedia learning[16,17].

Geoplay P\&T using pictures and on-screen text as a presentation strategy and caused sensory memory become overloaded in visual channel because players must read the words and see the pictures with their eyes.This increased cognitive load in working memory because people have limited capacity to process a new information. As a result, the new information was interrupted to be integrated with prior knowledge in long-term memory. By contrast, Geoplay P\&N have pictures and narration as a presentation strategy. It is the most efficient way because players canlisten to the words with their ears in narration and can view the pictures with their eyes. As a result, it can reduce cognitive load in working memory because in this way it does not compete with pictures for new information in the visual channel. Thisallows new information to be integrated with prior knowledge in long-term memory[16,20,22,25].

Results also contrast there are students and teachers have a perception that pictures and printed word or text on-screen can increase knowledge[8].Each teacher is particularly advised to use animation or visuals and spoken words during the teaching process to reduce the student's cognitive load in working memory.

This study concludes every GBL development needs to take advantage of the neurotransmitters dopamine that is capable of producing positive feelings and enable the player to think innovatively to resolve a problem. Additionally, theGBL development should have specific objectives, real-world mechanics and use visual with narration as a presentation strategy.

A future study is to find out the effects LOTS and HOTS students when playing virtual reality (VR) and 2 dimensions games like Geoplay. Both games have specific objectives, real-world mechanics and use visual with narration as a presentation strategy, only different in types of games. This is because there are those who argue VR games more effective if interacting with complex environments, such as surgery[20].Nowadays many apps can be used to develop VR 
The International Journal of Multimedia \& Its Applications (IJMA) Vol.9, No.4/5/6, December 2017

games like Game Guru. This will make it easier for teachers to develop VR games to attract students in learning.Therefore, this further study is very important to do.

\section{ACKNOWLEDGEMENTS}

Thanks to the Education Office Hilir Perak and Bagan Datuk District (PPD), Excellent Teachers' Council Hilir Perak and Bagan Datuk District and Geography Committee Hilir Perak and Bagan Datuk District because of provided ideas and comments on Geoplay game design.

\section{REFERENCES}

[1] Apter, M. J. (2007). Danger: Our quest for excitement (6th ed.). Oxford: One World Publications.

[2] Ashbay, F. G., Isen, A. M., \& Turken, A. U. (1999). A neuropsychological theory of positive affect and its influence on cognition. American Psychological Association, Inc., 106(3), 529-550.

[3] Bahagian Pembangunan Kurikulum Kementerian Pendidikan Malaysia. (2015). Geografi: Dokumen Standard Kurikulum dan Petaksiran Tingkatan 1. Putrajaya: Kementerian Pendidikan Malaysia.

[4] Connolly, T. M., Boyle, E. A., MacArthur, E., Hainey, T., \& Boyle, J. M. (2012). A systematic literature review of empirical evidence on computer games and serious games. Computers and Education, 59, 661-686.

[5] Debra, S. H. (2011). Compass games. Journal of Physical Education, Recreation \& Dance, 82(1), 16 22. http://doi.org/10.1080/07303084.2011.10598556

[6] Farber, M. (2015). Gamify your classroom: A field guide to game-based learning. New York: Peter Lang.

[7] Farrell, D., \& Moffat, D. C. (2014). Adapting cognitive walkthrough to support game based learning design. International Journal of Game-Based Learning, 4(3), 23-34. http://doi.org/10.4018/ijgbl.2014070103

[8] Fenesi, B., Heisz, J. J., Savage, P. I., Shore, D. I., \& Kim, J. A. (2014). Combining Best-Practice and Experimental Approaches: Redundancy, Images, and Misperceptions in Multimedia Learning. The Journal of Experimental Education, 82(2), 253-263. http://doi.org/10.1080/00220973.2012.745472

[9] Fullerton, T., \& Zimmerman, E. (2014). Game design workshop: A playcentric approach to creating innovative games (3rd ed.). Broken Sound Parkway NW: Taylor \& Francis.

[10] Gilbert, S. (2016). Designing Gamified Systems: Meaningful play in interactive entertainment, marketing and education. Burlington: Focal Press.

[11] Kapp, K. M., Blair, L., \& Mesch, R. (2014). The gamification of learning and instruction fieldbook: Ideas into practise. San Francisco: Wiley.

[12] Khairuddin, N., Che Zalina, Z., Nor Azah, A. A., \& Norhisham, M. N. (2017). Reka bentuk gamifikasi pembelajaran Geografi berasaskan permainan Geoplay. Geografi, 5(1), 46-60.

[13] Koster, R. (2013). Theory of fun for game design (2nd edi.). Sebastopol: O'Reilly Media.

[14] Maizatul Hayati, M. Y. (2017). Alatan pembelajaran teradun. In M. Y. Maizatul Hayati \& A. Ummu Husna (Eds.), Pembelajaran Teradun: Trend, Isu dan Amalan (pp. 35-46). Tanjong Malim: Universiti Pendidikan Sultan Idris.

[15] Marczewski, A. C. (2015). Even ninja monkeys like to play: Gamification, game thinking and motivational design. Charleston: Createspace Independent Publishing.

[16] Mayer, R. E. (2009). Multimedia learning (2nd edi.). New York: Cambridge University Press.

[17] Mayer, R. E. (2014a). Cognitive theory of multimedia learning. In R. E. Mayer (Ed.), The Cambridge Handbook of Multimedia Learning (2nd ed., pp. 43-71). New York: Cambridge University Press.

[18] Mayer, R. E. (2014b). Computer games for learning: An evidence-based approach. Cambridge: MIT Press. 
[19] Mayer, R. E. (2016a). The role of metacognition in STEM games and simulations. In H. F. O’Neil, E. L. Baker, \& R. S. Perez (Eds.), Using Games and Simulations for Teaching and Assessment (pp. 273301). New York: Routledge Taylor \& Francis Group.

[20] Mayer, R. E. (2016b). What Should Be the Role of Computer Games in Education? PolicyInsights from the Behavioral and Brain Sciences, 1-7. http://doi.org/10.1177/2372732215621311

[21] Mayer, R. E. (2017). Using multimedia for e-learning. Journal of Computer Assisted Learning. http://doi.org/10.1111/jcal.12197

[22] Moreno, R. (2006). Does the modality hold for different media? A test of the methods-affectslearning hypothesis. Journal of Computer Assisted Learning, 22, 149-158.

[23] Oviatt, S. (2013). The design of future educational interfaces. New York: Routledge Taylor \& Francis Group.

[24] Rajendran, N. S. (2010). Teaching \& acquiring higher-order thinking skills: Theory \& practice. Tanjong Malim: Universiti Pendidikan Sultan Idris.

[25] Sweller, J., \& Low, R. (2014). The modality principle in multimedia learning. In R. E. Mayer (Ed.), The Cambridge Handbook of Multimedia Learning (2nd ed., pp. 227-246). New York: Cambridge University Press.

[26] Sylvester, T. (2013). Designing games. Sebastopol: O’Reilly Media.

[27] Tan, W. H. (2015). Gamifikasi dalam pendidikan: Pembelajaran berasaskan permainan. Tanjong Malim: Universiti Pendidikan Sultan Idris.

[28] Tang, S., Hanneghan, M., \& Rhalibi, A. El. (2009). Introduction to games-based learning. In T. Connolly, M. Stansfield, \& L. Boyle (Eds.), Games-based learning advancements for multi-sensory human computer interfaces: Techniques and effective practices (pp. 1-17). Hershey: IGI Global.

[29] Trussell, M. E. (1986). Teaching basic Geographical skills: Map and compass activities. Journal of Geography, 85(4), 169-173. http://doi.org/10.1080/00221348608979414

[30] Watters, R. (1996). Navigating from the classroom to the outdoors teaching map and compass. Journal of Physical Education, Recreation \& Dance, 67(5), 55-56. http://doi.org/10.1080/07303084.1996.10607401

[31] Whitton, N. (2014). Digital games and learning: Research and theory. New York: Routledge.

\section{AUTHORS}

Khairuddin bin Nisa is a member of the Excellent Teachers Council Bagan Datuk District. Experienced teaching Geography for 18 years. Interested in gamification and now currently design learning module using gamification system

Che Zalina binti Zulkifli interest inWireless Communication, Embedded Systems (microprocessor, microcontroller), IoT,Mobile Systems, RFID, Real-Time Monitoring Systems, Instructional Technology in Education, M-Learning, Education Engineering, H2M-M2M (Machine to Machine Communication), Environmental Care-Green Technology,Computer Architecture, Advanced Internet Application, Next Generation Internet, Software Testing, and Programming.

Nor Azah binti Abdul Aziz interest in Gestural Interface Design, Child Computer Interaction, Multimedia Application Development, Islamic Spiritual Psychology , Information Tecnology, Internet/Web Filtering, Internet \& Society.
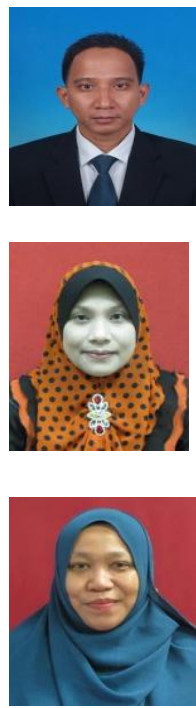